Michael D. Bordo is professor of economics at Rutgers University and a research associate of the National Bureau of Economic Research. David C. Wheelock is an assistant vice president of the Federal Reserve Bank of St. Louis. The authors thank J im Bullard, Bill Dewald, Anna Schwartz, Peter Yoo, and workshop participants at Indiana University, Indiana-Purdue University, and the Federal Reserve Bank of St. Louis for helpful comments, and Heidi Beyer for research assistance.

\section{Price Stability and Financial Stability: The Historical Record}

\author{
Michael D. Bordo \\ David C. Wheelock
}

D uring the past decade, many countries have set explicit inflation targets and mandated inflation control as the paramount objective of monetary policy. ${ }^{1}$ Some critics of the view that monetary policy should focus solely on minimizing fluctuations in the inflation rate or price level argue that such a narrow focus would compromise the stability of the financial system. A central bank with price stability as its sole objective might not respond to financial instability unless its inflation goal was threatened. The financial system and the economy as a whole might then suffer increased instability.

An alternative view argues that a monetary policy directed at maintaining price level stability would lessen both the incidence and severity of financial instability. Anna Schwartz (1988, p. 53) argues that a central bank "that was able to maintain price stability would also incidentally minimize the need for lenderof-last-resort intervention." Financial instability, according to Schwartz, has often been caused or made worse by fluctuations in the aggregate price level. A monetary policy that maintains price stability would thus also promote financial stability.

This article examines whether the financial history of the United States is consistent with Schwartz's claim that insta- bility in the price level exacerbates financial instability, a view we term the Schwartz Hypothesis. The most recent episodes of significant financial instability in the United States and other developed countries occurred in the 1970s and 1980s. In the United States, this instability was most evident in the form of widespread bank and savings and loan failures. Relative price shocksspecifically sharp declines in commodity and real estate markets after several years of price increases- were the proximate cause of the financial distress. The fluctuations in these markets, however, occurred in an era of aggregate price inflation followed by a sharp disinflation, which, according to Schwartz, increased the severity of the resulting financial distress.

Sustained inflation, according to the Schwartz Hypothesis, encourages speculative investment and borrowing because there exists an expectation that prices will continue to rise. When inflation abruptly declines, however, as it did in the early 1980s, borrower incomes may prove insufficient to repay loans that had been made with the expectation of continued price increases. The resulting rise in borrower defaults reduces the equity of lenders, possibly causing an increase in financial institution failures. In the absence of inflation and disinflation, real shocks, such as those affecting commodity markets in the 1970s and early 1980s, might still cause significant financial distress. The Schwartz Hypothesis argues, however, that if the aggregate price level is stable, or at least if its movements are fully predictable, then resources will be employed more economically, and financial distress, regardless of its proximate cause, will be less severe.

A definitive test of the Schwartz Hypothesis would require micro-level information about the decisions of households, firms, and financial institutions. Here we present an informal analysis of
${ }^{1}$ Typically, countries express their objectives in terms of the inflation rate- that is, the rate of change in the aggregate price level, rather than in terms of the price level itself. The terms price stability and inflation stability often are used synonymously, and we will do the same in this article except where the distinction is important. 
the timing of distress in U.S. financial history, supplemented by the histories of the United Kingdom and Canada, to gauge how closely associated financial instability and price level instability have been historically. This circumstantial evidence is largely consistent with the Schwartz Hypothesis. At a minimum, the historical association of severe financial instability with fluctuations in the price level would seem to support the arguments of those who favor a price stability mandate for monetary policy.

\section{THE SCHWARTZ HYPOTHESIS}

Schwartz contends that a monetary regime that limits fluctuations in the inflation rate also will tend to limit financial instability by lessening the information problems associated with evaluating the quality of al ternative investments. Price level instability, on the other hand, can exacerbate financial instability by increasing the uncertainty both borrowers and lenders face about the potential real returns to a project:

Both evaluate the prospects of projects by extrapolating the prevailing price level or inflation rate. Borrowers default on loans not because they have misled uninformed lenders but because, subsequent to the initiation of the project, authorities have altered monetary policy in a contractionary direction. The original price level and inflation rate assumptions are no longer valid. The change in monetary policy makes rate-of-return calculations on the yield of projects, based on the initial price assumptions of both lenders and borrowers, unrealizable. (Schwartz, 1995, p. 24)

Schwartz does not formally model how changes in the inflation rate can lead to financial instability, but her description fits well with the monetary misperceptions model of Lucas (1972 and 1973). ${ }^{2}$ In that model, individuals cannot distinguish (with certainty) shifts in relative prices from changes in the aggregate price level. This uncertainty can lead to resource misal location, which is corrected only once the true nature of a price change becomes known. Thus, for example, a firm might increase its production in response to an apparent increase in demand for its product as reflected by an increase in the market price. If, however, the producer understood that the price increase merely reflected an increase in the prices of goods and services generally, and not a change in relative prices in favor of the firm's output, the producer likely would not find it profitable to increase output. Uncertainty about whether the change in one price reflects a shift in relative prices or simply a change in the aggregate price level can thus cause a misallocation of resources.

This model is extended easily to incorporate financial decisions. Uncertainty about the nature of price changes can lead to bad forecasts of real returns to investment projects and, hence, to unprofitable borrowing and lending decisions. When borrowers and lenders forecast returns based on incomplete information or uncertainty about the future level of prices, mistakes that increase borrower defaults ex post can occur. Inflation tends to encourage overly optimistic forecasts of real returns and thus can lead to lending booms, both because of misperceptions regarding the nature of individual price changes and because the default risk premiums that lenders require may decline when inflation is expected to continue. By the same token, disinflation and especially deflation may lead to overly pessimistic forecasts or an increase in risk premiums and hence discourage the financing of projects that might otherwise be funded. ${ }^{3}$

When not fully anticipated or hedged, a change in the inflation rate can cause the realized real return to investment to deviate from what had been expected. Default rates in debt markets can thus be affected. An unanticipated disinflation, for example, can increase default rates by causing realized borrower incomes to fall below expectations. Although disinflation 
causes the real income to lenders on loans that do not default to exceed expectations, an increase in default rates could more than offset this gain and result in significant distress for lenders. The Schwartz Hypothesis argues that in the aggregate, financial instability is likely to be associated with disinflation because some projects will generate sufficient income to repay loans only if the rate of inflation equals or exceeds the rate that had been expected when the loans were made. ${ }^{4}$

\section{EMPIRICAL EVIDENCE ON THE SCHWARTZ HYPOTHESIS}

For the Schwartz Hypothesis to be important empirically, the following two conditions must be met: 1 ) fluctuations in the rate of inflation must, to some extent, be unexpected; and 2) borrowers and lenders cannot hedge completely against all possible inflation outcomes. If all movements of the inflation rate are fully anticipated, or if individuals can fully insure themselves against all such movements, then inflation will not exacerbate financial instability through the Schwartz mechanism. Neither condition is ever likely to hold completely of course, but the better anticipated inflation is, or the more able people are to insure against unfavorable outcomes, the less effect price level variability is likely to have on the stability of the financial system.

The form and possibly the severity of financial instability associated with either a real or inflation shock will be affected by a country's institutional environment. For example, banking panics, which are characterized by widespread conversion of deposits into cash, and possibly by suspension of cash payments, increases in bank failures, and monetary contraction, are much less likely to occur in the presence of an effective lender of last resort. Similarly, high bank failure rates are less likely in systems dominated by large, branching banks than in unit banking systems. N evertheless, regardless of the institutional environment, price level instability can still increase borrower defaults and thereby reduce banking system profits. Financial market structure and regulations can affect the nature of financial instability and perhaps even lessen the effects of inflation shocks, but price level instability will tend to exacerbate financial instability regardless of the institutional environment.

Similarly, the contribution of price level stability to stability of the financial system depends neither on the cause of specific price level movements nor on the nature of the monetary regime, except insofar as they affect the extent that changes in the inflation rate are anticipated. An abrupt decline in inflation following a sustained inflation will likely contribute to financial distress regardless of whether a country is on, for example, a gold standard regime or a fiat monetary system.

Throughout much of the nineteenth and twentieth centuries, the United States was on a gold standard of one sort or another. Under a gold standard, real shocks to the demand or supply of gold cause changes in the money stock and, over the long term, the price level. The underlying shock might be an adverse movement in the trade balance, for example, leading to a gold outflow, monetary contraction, and, if sustained, a decline in the price level. There may well be theoretical reasons not to offset real shocks of this sort- the classical rules of the game, for example, held that gold flows should not be offset and that the price level should be permitted to adjust to restore equilibrium in the international gold market. Nevertheless, one consequence of an unstable price level may well be an increase in financial instability. Even if there are reasons to permit some movement in the price level, if financial distress is worsened by price level instability, then financial instability could be lessened by limiting fluctuations in the price level, and price stability and financial stability should be considered complementary, rather than competing, policy objectives. We now turn to the historical record to gauge whether there may be support for the proposition that inflation

\footnotetext{
${ }^{4}$ Although Schwartz emphasizes how inflation increases the difficulty of projecting real returns for both borrowers and lenders, variability in the price level, according to Schwartz (1988, p. 49), can also worsen problems associated with asymmetric information between borrowers and lenders because "fraud and mismanagement are more likely to gain ground in conditions of price variability, and institutions of unimpeachable standards of risk management may make judgments that later turn out to be mistaken, if not disastrous."
} 


\section{THE SCHWARTZ HYPOTHESIS AND THEORIES OF FINANCIAL CRISIS}

The Schwartz Hypothesis is not a theory of financial crisis, but rather an explanation of how price level instability can lead to or exacerbate financial distress and possibly lead to a crisis. Moreover, the mechanism Schwartz describes is compatible with a variety of explanations of why crises occur, which we briefly describe here.

We define a financial crisis as a banking panic, which is an event characterized by widespread depositor runs on banks, leading to a decline in the deposit/currency ratio and possibly many bank failures. A banking panic is also characterized by contagion, or runs, on solvent banks. Before the Federal Reserve was established, panics typically ended in suspension of convertibility of deposits into currency. Other researchers use the term financial crisis to describe a variety of episodes in which sudden losses occur in financial markets or firms. Such episodes could include a sudden increase in bank failures not associated with depositor runs on the banking system as a whole (as occurred in the United States during the 1980s), a stock market crash, failures in the non-bank financial sector, such as the commercial paper market, or a currency crisis. ${ }^{5}$ Where important, we will make the distinction between financial crises, banking panics, and other types of financial distress clear.

Financial instability can have either monetary or non-monetary causes and may be solely domestic or spread among countries. The monetarist approach, specified for example by Friedman and Schwartz (1963) and Cagan (1965), identifies financial crises with banking panics that either cause or aggravate monetary contractions. According to monetarists, banking panics occur when the public loses confidence in the ability of banks to convert deposits into currency. ${ }^{6}$ In a fractional reserve banking system, attempts by the public to convert deposits into currency en masse, if not offset, will contract the stock of money and lead to widespread failures of otherwise sound banks.

A second theory of financial crises (defined broadly) relates financial instability directly to business cycle turning points, regarding crises and contractions in economic activity as inevitable consequences of the excesses of economic booms. Modern proponents of this financial fragility view include M insky (1977), Kindleberger (1978),

${ }^{5}$ Schwartz (1986) makes the distinction between real and pseudo financial crises. The former is a banking panic or stock market crash leading to a scramble for currency or central bank liabilities (high-powered money); the latter refers to all other events. Pseudo crises are marked by significant loss of wealth but no connection to the money supply or payments system.

${ }^{6}$ There have also been settings in which banks issue notes that are convertible into some commodity, such as gold. In these settings, a panic can occur if noteholders fear the inability of banks to redeem their notes for the commodity.
Kaufman (1986), Friedman (1986), and King (1994), who extend arguments made by Fisher (1932 and 1933).

According to Fisher, business cycle upturns are triggered by exogenous factors that provide new, profitable investment opportunities in key sectors of the economy. Rising prices and profits encourage more investment and also speculation for capital gains. Much of the process is debt financed, primarily by bank loans, which, in turn by increasing deposits and the money supply, increase the price level. A general optimism, or euphoria, takes hold and increases monetary velocity and further fuels the expansion, while rising prices, by reducing the real value of outstanding debt, encourages further borrowing. The process continues until a general state of overindebtedness is reached, that is, the point at which individuals, firms, and banks have insufficient cash flow to service their liabilities. At this point, the financial system is vulnerable to crisis.

The inability of borrowers to repay their debts leads to distress selling, which, if widespread, produces a decline in the price level. As loans are extinguished, bank deposits and the money supply decline, further lowering the price level. Deflation then increases the real burden of remaining debt, leading to further bankruptcies and declining economic activity, a process referred to as debt-deflation. The process continues until either widespread bankruptcy has eliminated the overindebtedness or a reflationary monetary policy has been adopted. Once recovery begins, however, the whole process will repeat itself. 


\section{REVIEW}

SEPTEMBER/ O CTOBER 1998

The principal difference between the monetarist approach and the financial fragility-debt-deflation approach concerns the role of monetary policy. Monetarists argue that crises are triggered by exogenous monetary shocks, whereas proponents of the financial fragility view believe that the financial system is inherently unstable and that crises arise mainly because euphoria at business cycle peaks encourages uneconomic lending that sows the seeds of its own collapse. Fractional-reserve banking, however, provides a key mechanism by which crises and deflation propagate in both the monetarist and financial fragility views.

Diamond and Dybvig (1983) suggest that the maturity mismatch of bank assets and liabilities provides an additional source of instability within the banking system. Banks transform illiquid assets into liquid financial assets by offering liabilities with a different, smoother pattern of returns over time. The illiquidity of bank assets leaves banks vulnerable to depositor runs, however, and only the presence of a lender of last resort or deposit insurance can prevent banking panics.

Asymmetric information, in which lenders are less informed than borrowers about the potential returns of alternative projects, provides an alternative source of financial instability. Lenders, unable to distinguish good from unsound loans, might ration credit or disproportionately discourage good quality borrowers by adding a lemons premium to interest rates. Heightened uncertainty, perhaps caused by instability of the price level, that makes screening of borrowers more difficult can worsen such adverse selection problems.

The asymmetric information approach explains bank panics as stemming from the fact that depositors cannot costlessly value individual bank assets, and hence have difficulty in monitoring the performance of banks (Jacklin and Bhattacharya, 1988). A panic can occur when new information causes depositors to perceive an increase in the riskiness of bank assets generally, but incomplete information prevents depositors from distinguishing sound banks from potentially insolvent banks (Calomiris and Gorton, 1991). A decline in asset values or disinflation can be one source of new information triggering panic among depositors. By reducing the net worth of borrowers, falling prices can also increase agency costs and thereby adverse selection because borrowers have less to lose by default. Thus disinflation can discourage lending and further disrupt the financial system or contribute to a decline in economic activity.

The Schwartz Hypothesis is compatible with any of the mechanisms of financial crises described here. Like the financial fragility view, Schwartz argues that financial instability occurs because of inefficient lending during economic booms associated with inflation. ${ }^{7}$ But, whereas proponents of the financial fragility model attach an air of irrational behavior to such lending, Schwartz argues that unproductive lending occurs because inflation makes discerning the quality of borrowers and projects more difficult. Thus price instability worsens the information problems lenders face. Like the asymmetric information model of crises, inflation may make it more difficult for lenders to uncover the true quality of borrowers. However, inflation also causes information problems about potential real returns that are common to both lenders and borrowers. Misinterpreting inflation as increases in relative prices could encourage lenders to make unproductive loans, whereas disinflation could discourage lending, again by making it difficult to distinguish relative price changes from movement of the aggregate price level.

\footnotetext{
${ }^{7}$ Gavin and Hausman (1996) make a similar argument. They contend that lending booms, which may be associated with rapid monetary expansion, are characterized by falling credit standards and increased difficulty with evaluating credit risks. Bad loans are revealed when economic activity declines, causing increased bankruptcies and stress on the banking system.
} 
instability exacerbates financial instability in general.

\section{Testing the Schwart Hypothesis}

A test of the Schwartz Hypothesis using macroeconomic data presents several challenges. First, the hypothesis does not address the underlying causes of financial instability and argues only that price level instability will contribute to financial distress-episodes in which banks or other intermediaries suffer unusually high losses as a result of borrower default. Financial distress can be triggered by shocks to relative prices, however, as well as by shocks to inflation. Thus the occurrence of financial instability during periods when the price level was relatively stable is not necessarily evidence against the Schwartz Hypothesis.

A second difficulty arises because the hypothesis pertains only to unexpected disinflation. If a disinflation were widely anticipated, the mechanism of a lending boom followed by financial instability described by Schwartz would not apply. We argue that the substantial disinflations after the Civil War, World War I, and World War II were not accompanied by serious financial disruptions because those disinflations were widely anticipated outcomes of the gold standard monetary regime. ${ }^{8}$ Other, smaller disinflations have been accompanied by major financial crises, perhaps because those disinflations were unexpected.

The nature of the monetary regime can affect the extent to which changes in the price level are predictable. Under a gold standard, for example, the price level tends to be mean-reverting. That is, offsetting increases (decreases) in the price level tend to follow declines (increases) in the price level (Bordo, 1981). Similarly, when the public views a government's commitment to the gold standard as credible in the long run, it will come to expect that any inflation occurring during a period of gold suspension will be offset by deflation (Bordo and Kydland, 1995). In the classical gold standard era, 1879-1913, however, inflation in the United States was virtually a random walk, with just a slight tendency for deflation to follow inflation after two or more years (Barsky, 1987).

Since the establishment of the Federal Reserve System in 1914, inflation has become increasingly persistent, implying that forecasts of inflation closely resemble current inflation (Barsky, 1987). This period has witnessed the decline and eventual abandonment of the gold standard in favor of a government-managed fiat standard. Sudden changes in the rate of inflation or its direction, as occurred in the early 1980s, seem especially difficult to anticipate in a fiat monetary regime, particularly when central bank objectives are not clear. Because inflation historically has been difficult to predict under all types of regimes, however, we make no attempt in this article to estimate the extent to which changes in inflation were anticipated, though any formal analysis of the Schwartz Hypothesis would need to make such a distinction.

A third problem we face in estimating the contribution of price level instability to financial instability is one of reverse causality. Financial instability that directly causes a decline in the growth rate of the money stock can, in turn, cause disinflation. Indeed, banking panics have occurred often before large deflations. Identifying the effect of price level instability on financial stability is thus especially difficult for the nineteenth century, when banking panics occurred relatively frequently. However, crosscountry comparisons, as well as cross-regime evidence within a country, enable us to sort out these difficulties to some extent. With such comparisons we can show that financial instability can take many forms, depending on the extant institutional environment. And, because financial distress that produces a negative monetary shock will likely have more subsequent effect on the price level than other forms of financial distress, we can provide more convincing evidence for the Schwartz Hypothesis by comparing similar episodes of price instability across countries with different institutions and thus different forms of financial distress. We begin, however, by 
focusing on the financial history of the United States.

\section{THE U.S. HISTORICAL EXPERIENCE}

We now examine the history of financial instability in the United States to gauge the extent to which the American experience before the 1980s is consistent with the Schwartz paradigm. Specifically, we attempt to determine how closely episodes of banking instability align with instability in the rate of inflation. We find that most episodes of serious financial instability in the United States were associated with disinflations and that all large disinflations, except those immediately following wars, were accompanied by financial instability. Our evidence does not prove that financial instability was made worse by price level instability; however, the proximity of episodes of banking distress to inflation and disinflation is circumstantial evidence in favor of the Schwartz Hypothesis.

The average annual inflation rate for the United States from 1789 to 1996 is plotted in Figure 1. Banking panics occurred in years marked with black arrows on the figure; other years characterized by unusually high numbers of bank failures or losses to bank depositors, but not panics, are marked with blue arrows. The Schwartz Hypothesis is not a theory of banking crises, but rather an explanation of how inflation variability can exacerbate financial distress, which may or may not be reflected in crises. We focus on the timing of banking disruptions because the information about financial distress in the nineteenth century is largely anecdotal, with only fragmentary data existing on business failures, bank loan losses, and even bank failures-especially for the early part of the century. M oreover, the presence of unit banking and the absence of a lender of last resort meant that in the nineteenth century banking panics often accompanied other forms of financial distress. ${ }^{9}$ Fortunately, nineteenth century banking panics and other episodes of

\section{Figure 1}

U.S. Annual CPI Inflation Rate

1789-1996 (year-to-year change in log CPI)

Percent

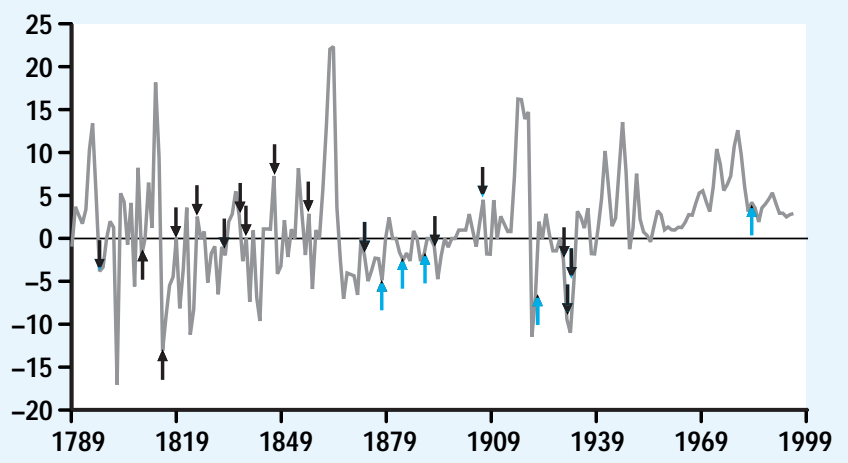

NOTE: Black arrows represent years in which banking panics occurred. Blue arrows mark years characterized by unusually high numbers of bank failures or losses to bank depositors, but not with banking panics.

${ }^{9}$ Not all episodes of banking distress were equally severe, of course, and in future work we plan to rank the episodes by their severity so that we can estimate explicitly their association with price instability.

${ }^{10}$ Schwartz (1988) lists years in which banking panics occurred, citing Thorp (1926). We use her dates, except that, following Thorp, we mark panics in 1792 rather than 1793 and 1809 rather than 1810 . For years of high banking distress not marked by outright panic, we cite Sprague (1910) and Friedman and Schwartz (1963). To limit clutter, we plot only one arrow each for the 1920 s and 1980 s, even though bank failures were numerous in several years of each decade. For 1789-1947, the inflation rate is based on cost-of-living estimates in David and Solar (1977). For 19481996, we plot the consumer price index of the Bureau of Labor Statistics.

${ }^{11}$ The Coinage Act of 1792 defined the dollar in terms of both gold and silver, and the bimetallic standard prevailed until the Civil War. 


\section{Figure 2}

U.S. Annual CPI Inflation Rate

1789-1859 (year-to-year change in log CPI)

Percent

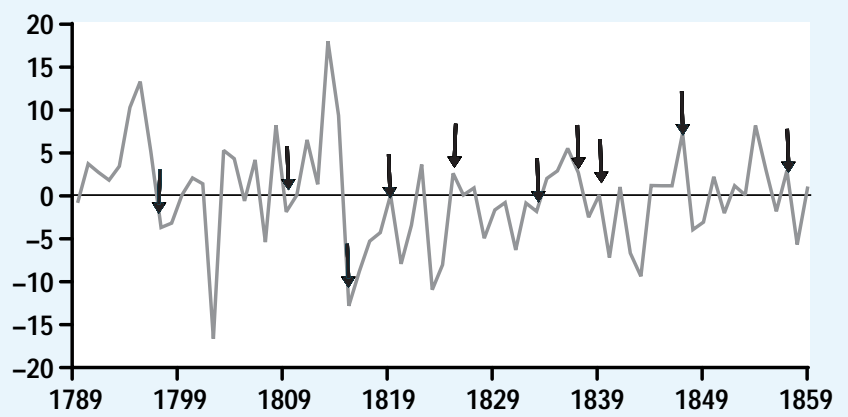

NOTE: Arrows mark years in which banking panics occurred.

${ }^{12}$ Smith and Cole (1935) provide an excellent description of American economic growth and fluctuations during 1790-1860.

${ }^{13}$ The possibility exists, of course, that the apparent high instability of the U.S. price level and national product merely reflects the poor quality of economic data from this period. Measurement problems do make historical comparisons suspect, but there seems to be widespread agreement among economic historians that the U.S. economy was more stable after the Civil War than before. See Calominis and Hanes (1994). growth followed by episodes of severe financial and economic distress. ${ }^{12}$ The era was characterized by numerous shocks, both nominal and real, which produced frequent, large inflows and outflows of gold, with consequent sharp fluctuations in the money stock and price level. Although the pace of financial development in this period was rapid (see, for example, Sylla [1998]), the American financial system and world capital markets were frequently overwhel med by shocks that reverberated to the gold market. The American economy appears to have suffered considerable instability. ${ }^{13}$

The annual inflation rate from 17891859 , as reflected by annual percentage changes in the David and Solar (1977) cost-of-living index, is plotted in Figure 2. We also mark years in which banking panics occurred. The lack of continuous data on banking distress, except anecdotal information about the incidence of panics, forces us to restrict our analysis of financial instability in this era to banking panics. Though the Schwartz Hypothesis is not a theory of panics, banking panics in this era appear to have coincided with episodes of banking distress in general; consistent with the Schwartz Hypothesis, most panics, especially the most severe, coincided with disinflation.

1797. The 1790 s were generally prosperous years-agricultural prices rose, as did consumer prices generally. Instability occurred occasionally, however, driven mainly by fluctuations in commodity prices. Some financial instability occurred between 1792-93, but the economy grew vigorously during 1794-95. Thorp (1926, p. 114) described 1795 as a year of "prosperity," with "active internal trade; land speculation; many new companies formed" and "booming" foreign trade. Banks, according to Thorp, "multiplied rapidly" in 1795. David and Solar's (1977) consumer price index rises sharply throughout 179496. The price level fell in 1797, however, and was accompanied by a recession and major banking panic. The Schwartz $H$ ypothesis seems broadly consistent with the historical description of the 1790s provided by Thorp's (1926) anecdotal evidence and the David-Solar (1977) price index. Financial distress in 1796-97 occurred in a disinflationary environment that followed several years of inflation.

The decline in commodity prices in 1797 proved wrong those who had bet on continued price increases by borrowing money to speculate on real estate. Declining prices and incomes left borrowers unable to repay lenders, and a banking crisis resulted. This scenario was to be repeated many times in American economic history-most recently in the 1980s.

Falling commodity and real estate prices have been the proximate cause of financial distress, but the most serious episodes of financial instability have occurred when aggregate price inflation rose with commodity prices and declined as commodity prices fell. In other words, though financial instability often has its origins in a particular sector of the economy, accompanying fluctuations in the general price level appear to worsen the financial distress. Inflation is thought to make discerning the nature of individual price changes more difficult, making mistakes in the allocation of resources more likely to occur (Lucas, 1972). Falling prices will reveal those mistakes in the form of increased insolvencies, bank failures, and other forms of financial distress. It is impossible to say how 
serious the financial distress of 1797 or later years would have been in the absence of the prior inflation. The Panic of 1797 and the other severe pre-Civil War crises did, however, occur in disinflationary periods that followed substantial inflations.

1815. Except for a precipitous decline in commodity prices in 1802, which apparently did not trigger a banking panic, the price level was relatively stable during the first decade of the nineteenth century. A minor panic occurred in 1809 , but there was no serious financial disruption until 1815.

The economy grew rapidly in 1810 , according to Thorp (1926, p. 116), and began a period of "rapid expansion" of bank notes and rising commodity prices. The War of 1812 put a "temporary check" on economic activity, though commodity prices continued to rise sharply. The year 1814 was characterized by "active speculation, large imports, and no exports," according to Thorp (1926). M onetary conditions grew tight in the second half of the year, however, and banks outside of $\mathrm{New}$ England suspended payments in August. The year 1815 witnessed "continued speculation, especially in land," but then a sharp decline in commodity prices and "financial chaos" (Thorp). As with the crisis of 1797, the Panic of 1815 occurred early in a disinflationary period that followed a substantial inflation.

1819. The next panic occurred in 1819. Deflation was the rule from 1815 to the mid-1830s, with an average annual rate of price change of - 4 percent between 1815 and 1833 . The commodity price decline was especially sharp in 1818-19, the effects of which are described by Smith and Cole (1935, pp. 20-21) as follows:

These price declines meant serious losses to merchants who had speculated in commodities; they portended decreased money incomes to the American farmer; and they precipitated the first major banking crisis of [the period 1790-1820]. Banks with extended loans to speculators were now confronted with a demand for specie... Contraction of discounts (loans) at this time became a necessity, and the curtailment of bank loans made the position of the American merchant even more difficult... The collapse of European markets for American export products, and internal predisposition,' the over-extended condition of banks and mercantile credit, became indeed disastrous.

As with the panics of 1797 and 1815, the financial crisis of 1819 was triggered apparently by prices and incomes that were bel ow what borrowers and lenders had forecast.

1825. The economy began to revive in 1821 , but prices remained stagnant. The CPI fell 11 percent in 1823 and 8 percent in 1824, and another banking panic occurred in 1825. According to Thorp, in 1825 commodity prices rose "with feverish speculation to autumn, when they collapsed." Economic activity then declined and unemployment was "severe."

Whether the 1825 episode is consistent with the Schwartz Hypothesis is unclear. David and Solar's (1977) consumer price index falls sharply in 1823-24, but is essentially unchanged in 1825-26. The panic of 1825 occurred in July, which appears to have been just before commodity prices collapsed. The panic, however, may have been a delayed result of the deflation of 1823-24.

The minor panic of 1833 also does not obviously conform to the Schwartz Hypothesis. The early 1830 s were generally prosperous, with moderate inflation that continued after the panic of 1833. Disruptions surrounding President Jackson's "war" with Nicholas Biddle and the Bank of the United States may have caused the panic. According to Thorp, "easier money became very tight," and the panic came late in the year, following Jackson's redistribution of public monies to the socalled pet banks in September and an "extraordinary" contraction of credit by the Bank of the United States.

1837-39. The panic of 1837 ushered in an exceptionally severe episode of deflation and economic depression. Inflation, 
caused by inflows of M exican silver (Temin, 1969), had prevailed since 1833, accompanied by "active speculation, especially in land" (Thorp, 1926). Thorp writes that "great activity and excited speculation" prevailed in the first quarter of 1837, but by mid-year the banking system was in crisis.

Temin (1969) argues that the crisis came in two stages. The first stage came in 1836 when the Bank of England increased Bank Rate and refused to discount for commercial banks engaged in AngloAmerican trade. These actions, which reflected the Bank's response to a substantial loss of specie reserves, increased interest rates and restricted the supply of credit in the United States. The second crisis stage came in early 1837 , when the price of cotton dropped precipitously. According to Temin (1969, p. 141), "as a result of this fall, debts secured by cotton became uncollectible, merchants holding such debt failed, banks found their assets illusory or at least illiquid, and they refused to honor their liabilities."

The Panic of 1837 was accompanied by some 600 bank failures-a "slackening and depression; many failures; unemployment; complete collapse of the cotton market...and commodity price decline" (Thorp, 1926). A "slight revival" in 1838 and early 1839 brought a revival of land speculation, according to Thorp, but prices collapsed again, and another banking panic occurred in the fourth quarter of 1839. In all, the price level fell 23 percent between 1837 and 1843 (David and Solar, 1977).

The Panic of 1837 was triggered by credit contraction and a precipitous drop in the price of cotton. The 1839 crisis followed a second collapse in commodity prices. One might question how much disinflation, as opposed to a shift in relative prices, contributed to the panics. $\mathrm{H}$ ard evidence of a disinflationary role is illusory; however, the fact that the panics occurred after several years of a rapid increase in the money supply and rising inflation, followed by a collapse in the prices of output in the economy's dominant sector - agriculture - suggests that unanticipated price decline played an important role in the crisis. Moreover, as Temin (1969, p. 146) notes, "it is a peculiarity of the antebellum financial structure that in a time of very flexible prices, many of the credit arrangements depended on the movements of a single price (the price of cotton)." A crisis of some severity would have occurred almost certainly in 1837, but the preceding inflation and the dominance of commodity prices in the aggregate price level indicates that price level instability exacerbated the financial distress.

1857. The economy remained depressed through 1843. Prices and economic activity rose in 1844, however, with the price level rising again in 1846. Consumer prices changed little throughout the remainder of the 1840s, whereas the 1850s witnessed strong economic growth and a rising price level. Thorp (1926) writes that speculation was "active" in 1852 and "extensive" in 1853, when commodity prices rose sharply. American commodity exports boomed during the Crimean War, though economic activity and the price level varied little during 1854-56. Money supply growth was rapid throughout the period, thanks to gold discoveries in California and banks' declining reserve ratios (Smith and Cole, 1935, pp. 116-35).

The Panic of 1857 was triggered by a collapse of western real estate and railroad stock prices (Calomiris and Schweikart, 1991). Much like the Panic of 1837, the 1857 crisis was associated with the collapse of a speculative bubble that followed several years of inflation. And, like 1837, some financial instability might well have occurred in 1857 in the absence of variability in the price level. The Schwartz Hypothesis suggests that inflation could have exacerbated the financial instability, however, by fostering an environment in which speculative lending was more likely to occur. That commercial bank reserves declined as a fraction of bank deposit liabilities over the decade before 1857 suggests that banks were 
taking greater risks (Smith and Cole, 1935, pp. 120-21). The occurrence of a major panic in 1857 is thus consistent with the Schwartz Hypothesis.

To summarize, the most serious episodes of banking instability of the preCivil War period appear to conform well to the Schwartz Hypothesis, occurring early in disinflationary periods that followed substantial inflation. These are the panics of 1797, 1815, 1837, 1839, and 1857. Other, less severe, panics occurred in $1809,1819,1825$, and 1833 and were less obviously associated with significant fluctuations in the price level. That the major financial disruptions of the era occurred immediately after episodes of substantial inflation had ended, however, is clear circumstantial evidence in support of the Schwartz view.

\section{From the Civil War to 1914}

From the end of the Civil War to World War I, the U.S. economy grew rapidly and became more diversified. The American financial system also became more developed, with considerably increased integration between regions within the United States and between the United States and the rest of the world. International capital markets absorbed substantially more of the shocks that formerly reverberated through the gold market. Hence, gold flows tended to be less sudden and dramatic, leaving the money supply and price level more stable than they had been before the Civil War.

The gold standard was, in effect, suspended during the Civil War, and the government issued inconvertible currency (i.e. "greenbacks") to help finance the war. Although the gold standard was not formally resumed until 1879, price level expectations formed during the war (especially as the war's outcome became more certain) could well have assumed that suspension would be temporary and that wartime inflation would be followed by a period of deflation. And, indeed, the United States experienced a prolonged deflation from 1866 to 1879 , with an

\section{Figure 3}

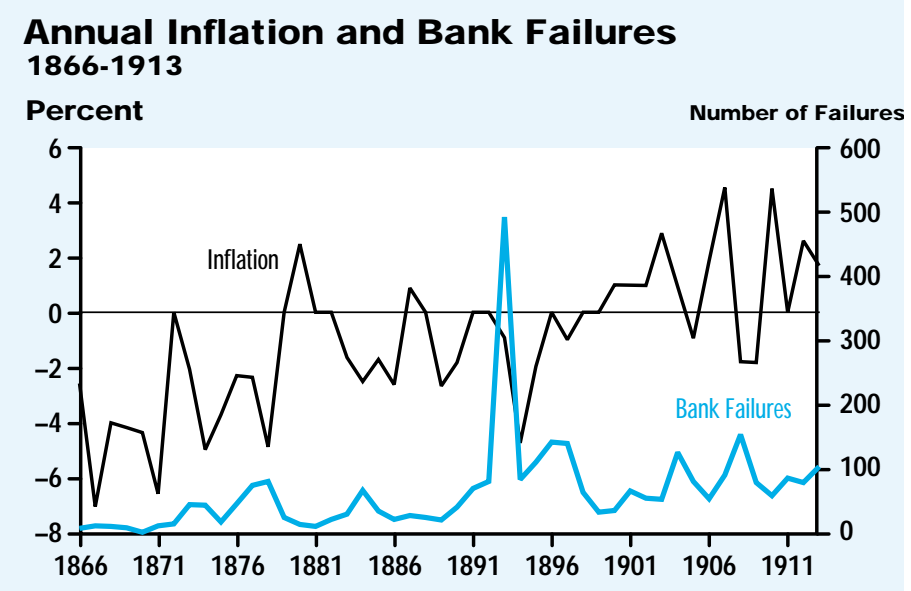

average annual rate of decline in the costof-living of 3.5 percent (David and Solar, 1977). Once resumption was accomplished, however, the price level was relatively stable until World War I.

Despite a sharp decline in the price level immediately following the Civil War, no serious financial instability occurred until 1873. The wartime experience illustrates that the effect of inflation on financial stability depends crucially on the monetary regime. The public tolerated wartime inflation and even accepted nominal yields on government debt that were below current inflation rates, because they believed that the value of money would be restored to its pre-war level soon after war's end (see Bordo and Kydland, 1995, and Calomiris, 1993). Moreover, because it was expected, postwar disinflation brought relatively little immediate financial disruption, despite the extreme inflation that occurred during the war.

Figures 3, 4, and 5 supplement the information about the timing of financial distress reflected in banking panics presented in Figure 1 and plot the inflation rate alongside bank failures, depositor losses in failed banks, and the annual standard deviation of the commercial paper interest rate between 1866 and 1913. Serious banking panics occurred in 1873, 1893, and 1907, but significant 
Figure 4

Annual U.S. Inflation and Deposit Losses in Failed U.S. Banks As A Percentage of Total Deposits in U.S. Banks

1866-1913

Deposit Loss Rate Inflation, Percent

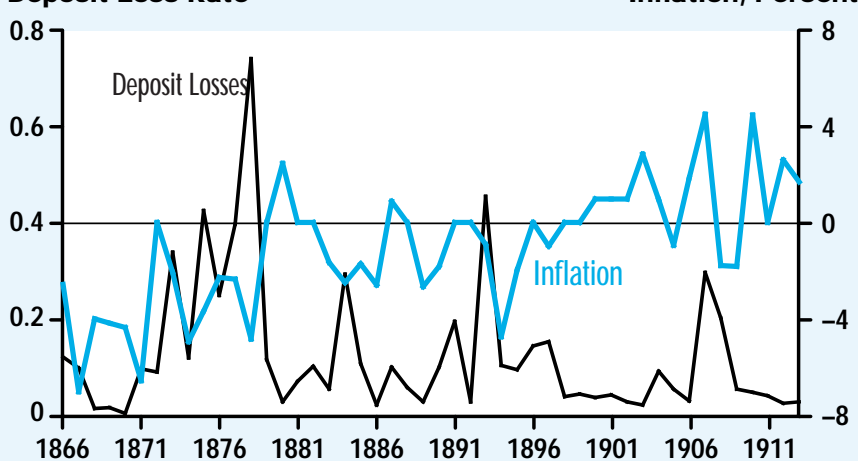

Source: Bordo, Rockoff, Redish (1996).

${ }^{14}$ Sprague (1910) is the classic history of the banking panics of this era.

15 Before the Civil War, the United States had been on been on a bimetallic (gold and silver) standard (though silver dollars had not circulated since 1836 because legislation in 1834 had under-valued silver relative to gold). During the war, unbacked currency was issued, but the question of how and when a metallic standard would be reinstated was left open. The Coinage Act of 1873 officially demonetized silver. Hence the drive to restore the dollar to its pre-war parity with gold may have entailed more deflation than would have been expected from a resumption of bimetallism which, presumably, would have meant more rapid money supply growth (see Friedman, 1990). The extent of deflation beginning in 1873 thus, to some extent, may have exceeded what had previously been anticipated. financial distress occurred also in 1878, 1884 , and $1890 .{ }^{14}$

1873. Like the Panic of 1857 , the proximate cause of the Panic of 1873 was a collapse of real estate values and railroad security prices, with the panic's capstone being the failure of the banking house, Jay Cooke and Company. The Panic of 1873 occurred during the long, post-Civil War deflation. The deflation had been interrupted briefly during 1871-72, however, when increasing prosperity and stable prices were accompanied by an increase in the money stock. The Panic of 1873, according to Friedman and Schwartz (1963, pp. 30-31), came after the money stock and business cycle had peaked. If the resumption of deflation in 1873 was to some extent unexpected, the Schwartz Hypothesis suggests that it may have contributed to the severity of loan defaults and bank failures in this period. ${ }^{15}$

The United States returned to the gold standard in 1879 . Mild deflation from 1879 to the mid-1890s was followed by mild inflation, and the price level in 1913 was essentially the same as it had been in 1879. As the statistics in Table 1 illustrate, the year-to-year movements in the price level during 1879-1913 were also small in comparison with those of 1789-1859, 1914-41, 1914-96, and 1946-96. The average annual inflation rate was never higher than 4.5 percent nor less than -4.7 percent between 1879 and 1913, and the standard deviation of the inflation rate was a mere 1.98. By contrast, between 1789 and 1859 , inflation rates ranged from -17.1 percent to 18.2 percent, with a standard deviation of 5.88. During the Federal Reserve era (1914-96), inflation averaged 3.3 percent, ranging from -11.5 percent to 16.3 percent, with a standard deviation of 5.13. Since World War II, inflation has averaged 4.25 percent, ranging from -1 percent to 13.6 percent, with a standard deviation of 3.26 .

Despite the price level being more stable during 1879-1914 than before the Civil War, the postwar period was not free of financial disturbances. Financial instability occurred in 1884 and 1890, and major banking panics occurred in 1893 and 1907. Each of these episodes was to some extent caused by monetary instability, coupled with institutional arrangements that made the banking system susceptible to panics. Indeed, the absence of banking panics in the United Kingdom in this period, which we discuss in a later section, reflected neither greater price level stability nor the absence of real economic shocks, but rather the Bank of England's effectiveness as a lender of last resort and the relatively high concentration of the U.K. banking industry, which prevented financial disturbances from becoming full-fledged banking panics.

1893. A serious banking panic occurred in 1893, apparently precipitated by a stock market crash and large gold outflow. Throughout the post-war period, the U.S. commitment to remaining on the gold standard was questioned, which may explain the general tendency for the United States to lose gold (Friedman and Schwartz, 1963, pp. 89-134). The gold outflow was temporarily interrupted in 1891-92, however, when U.S. commodity exports soared. Both the money stock and commodity prices increased in these two 
years, and the cost-of-living stabilized. The gold outflow resumed late in 1892, however, and a financial crisis ensued in the spring of 1893. The proximate cause of the crisis was a stock market collapse and increase in commercial failures, which awakened fears about the solvency of commercial banks. Sprague (1910, p. 154) also cites the combination of heavy farm debt and low commodity prices, along with rail road bankruptcies that were "due to oversanguine estimates of the future and reckless financing of the wildest sort" as contributors to the banking panic.

Deflation, which resumed late in 1892, may have contributed to the severity of panic, as Friedman and Schwartz (1963, p. 108) suggest:

A large number of mercantile failures during the first half of 1893 had excited alarm concerning the quality of bank loans. As in many such cases, however, a deeper cause was doubtless the preceding price deflation. Loans that would have been good and banks that would have been solvent if prices had been stable or rising became bad loans and insolvent banks under the pressure of price deflation.

Once again it appears that a sudden decline in the price level worsened an episode of financial instability.

1907. The deflation that followed the Civil War ended in the mid-1890s. Thereafter, the price level rose modestly through 1913. Between 1899 and 1907, the David-Solar (1977) cost-of-living index rose from 100 to 113. The trend was interrupted then, however, by the occurrence of a severe financial crisis in 1907 and a steep recession in 1907-08.

The initial disruption was caused apparently by an increase from 3.5 percent to 6 percent in the Bank of England's discount rate in September 1906, as the bank sought to stem a serious outflow of gold from London. The action had the effect of reversing the flow of gold to the United States and severely tightening U.S. money market conditions. A stock market

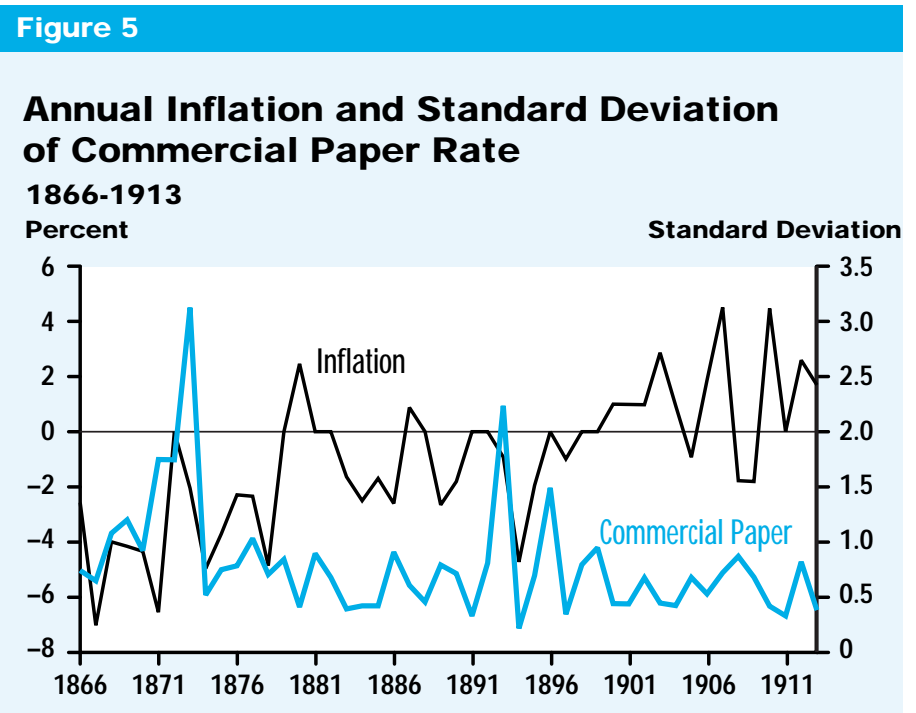

crash occurred in early 1907, and economic activity began to decline. The distress did not envelop the banking system until October, however, when depositor runs on trust companies spread to commercial banks. Then the money stock, which had been falling modestly because of gold outflows, collapsed, banks suspended cash payments, and the economy entered a sharp recession.

Like the panics of 1873 and 1893, the Panic of 1907 was not caused by instability in the aggregate price level. And, though each panic was preceded by a period of moderate price increase, at least of commodities, none of these panics offers strong support for the Schwartz Hypothesis- the pattern of inflation followed by disinflation simply was not large enough to have had a marked influence on the extent of financial instability. This seems especially true of 1907 when, despite a slight contraction of the money supply, prices continued to rise until the panic had occurred.

The banking panics of the post-Civil War era stemmed more from a particular vulnerability of American banks to crisis caused by unit banking and the absence of a lender of last resort. Given this institutional structure, serious banking panics could be triggered by relatively 
Table 1

Annual CPI In ation Rate Characteristics for Different Periods in U.S. History

\begin{tabular}{lcccc} 
& Average & Standard Deviation & Minimum & Maximum \\
\cline { 2 - 5 } $1789-1996$ & 1.38 & 5.70 & -17.06 & 22.45 \\
$1789-1859$ & -0.10 & 5.88 & -17.06 & 18.23 \\
$1879-1913$ & -0.02 & 1.98 & -4.74 & 4.53 \\
$1914-1996$ & 3.33 & 5.13 & -11.47 & 16.29 \\
$1914-1941$ & 1.40 & 7.16 & -11.47 & 16.29 \\
$1946-1996$ & 4.25 & 3.26 & -1.25 & 13.62
\end{tabular}

SOURCES: David and Solar (1977) for 1789-1947 and Bureau of Labor Statistics for 1948-96. minor events. Calomiris and Gorton (1991) argue that events, such as a stock market crash, the failure of a major financial or commercial firm, or a decline in commodity prices could trigger a banking panic by raising questions about the value of bank assets and hence bank solvency. Lacking information to discriminate among the portfolios held by different banks, depositors run on all banks. In the absence of a lender of last resort, commercial banks resorted to suspension of payments and cooperative arrangements to provide liquidity, such as the issuance of clearinghouse loan certificates (Gorton, 1985). Unit banking, however, made such coordination difficult, except at a local level, while also making the banking system more susceptible to crises stemming from localized shocks, such as a decline in commodity prices.

Short-run instability in the price level may well have contributed to the incidence and severity of financial instability between 1866 and 1913 . The Schwartz Hypothesis implies that financial instability would have been even greater in this period had there been episodes of high inflation and disinflation. The experiences of the pre-Civil War and Federal Reserve (post-1913) era-regimes suggest this might well be true.

\section{activity declined in 1920-21 is} unclear. Romer (1988) estimates that the recession was less severe than many researchers had thought previously.

\section{The Federal Reserve Era}

The Federal Reserve System was established in response to the recurrent banking panics of the post-Civil War era. The Fed was intended to solve perceived deficiencies in the banking and payments system, chiefly the apparent inflexibility of currency and bank credit supplies in response to fluctuations in demand. The Fed's founding coincided with the beginning of World War I in Europe, suspension of the international gold standard, and rising inflation.

Although the United States briefly embargoed gold exports during the war, postwar convertibility of the dollar to gold at its pre-war rate of $\$ 20.67$ per ounce was never seriously in doubt. After the war, however, large gold outflows, as well as a desire to halt inflation, caused the Fed to increase its discount rate sharply. Between October 1919 and June 1920, the rate was increased from 4 percent to 7 percent, where it stayed until May 1921. Precipitous declines in the stock of money and price level coincided with the Fed's action.

Unlike the post-Civil War deflation, which lasted some 30 years, the postWorld War I deflation in the United States was short lived, though steep. The money stock began to grow again in 1922, and the economy quickly revived. ${ }^{16}$ Moreover, despite the large price level decline, there was no banking panic in 1921 or later in the decade, perhaps because the post-war deflation had been anticipated. Many banks failed in 1921 and throughout the 1920s, however. But the failures were confined almost exclusively to small banks located in the rural Midwest and South. 
The high number of rural bank failures during the 1920s reflected dramatic shifts in relative prices-rising real prices of commodities during the war and falling real prices after the war-and unit banking. Rural economies boomed during the war, with rising incomes and land prices. Many farmers expanded their operations, buying new land and improving land that had not been farmed previously. Much of this expansion was financed with money borrowed from banks, whose numbers and assets in rural regions grew as rapidly as did their region's booming economies. ${ }^{17}$

As had occurred so often before, a sharp increase in commodity prices during the war years was matched by an equally sharp decline in the postwar-a decline that exceeded the decline in the aggregate price level. Once again, expectations of continued high output prices, which had justified the rising price of farmland and the borrowing to finance expansion, had been dashed. Falling incomes left borrowers unable to repay their loans, causing banks to fail. Bank failures were most numerous in the regions where farmland prices and the expansion of agricultural acreage had increased the most during the war (Alston, Grove, and Wheelock, 1994).

The banking distress of the 1920 s was caused primarily by sudden changes in relative prices that first favored and then hurt commodity producers and their lenders.

Aggregate price inflation and deflation could well have contributed to the distress, but the absence of financial disruption outside of commodity-producing regions suggests that relative price shifts had more to do with the rise of bank failures during the 1920s than did movements in the aggregate price level.

\section{The Great Depression}

The Great Depression was the most calamitous macroeconomic episode of the twentieth century. Between 1929 and 1933, national output declined by 30 percent, the price level fell some 24 percent, unemployment reached 25 percent of the labor force, and some 9,000 banks suspended operations. Financial crises included the stock market crash of 1929 and, beginning in 1930, banking panics of increasing severity.

Friedman and Schwartz (1963) emphasize the deflationary effect of banking panics during the Great Depression. The money multiplier dropped precipitously as bank customers sought to convert their deposits into cash and banks sought to convert illiquid assets into liquid reserves. Because the Fed failed to supply sufficient currency and bank reserves to offset the decline in the multiplier, the money stock fell some 30 percent. $^{18}$

Were the banking panics of the Great Depression themselves caused or worsened by deflation? The Schwartz Hypothesis argues that unanticipated disinflation, or the absence of full hedging against disinflation, will exacerbate financial distress. Falling prices in 1930-32 dramatically increased the real burden of debt on borrowers and many defaulted-contracts were not fully hedged. The extent to which the deflation of 1930-32 was anticipated is less clear.

There is substantial evidence that tight monetary policy, which the Fed imposed in 1928 to check the flow of bank credit to the stock market, contributed to the initial economic downturn (Schwartz, 1981; Hamilton, 1987). And, certainly, in failing to prevent or offset banking panics, the Fed's inaction permitted the money supply to fall precipitously during 1930-32. Unclear, however, is whether the Fed's inaction was predictable from its previous policies. Friedman and Schwartz (1963) contend, in essence, that a change in policy regime occurred with the death in 1928 of Benjamin Strong, governor of the Federal Reserve Bank of N ew York and the Federal Reserve System's leading figure. Strong pursued stabilizing policies during the 1920s, according to Friedman and Schwartz, and his death explains the apparent contrast in policy performance between the 1920s and early 1930s. This suggests that deflation would not have been expected from recent $F$ ed performance. Other researchers have considered the

\footnotetext{
${ }^{17}$ Eight largely rural states that had bank deposit insurance systems saw especially rapid increases in their banking systems as deposit insurance gave bankers an incentive to assume greater risks than would have otherwise been profitable. Uneconomic increases in the number of banks and in bank assets during the boom caused these states to have relatively high bank failure rates and asset declines after commodity prices collapsed. See Calomiris (1992), Wheelock (1993), and Alston, Grove, and Wheelock (1994).
${ }^{18}$ Numerous studies have recon- sidered the origins and effects of banking panics during the Great Depression. See Wicker (1996) for a recent view.




\section{Figure 6}

U.K. Annual CPI Inflation Rate

1791-1996 (year-to-year change in log CPI)

Percent

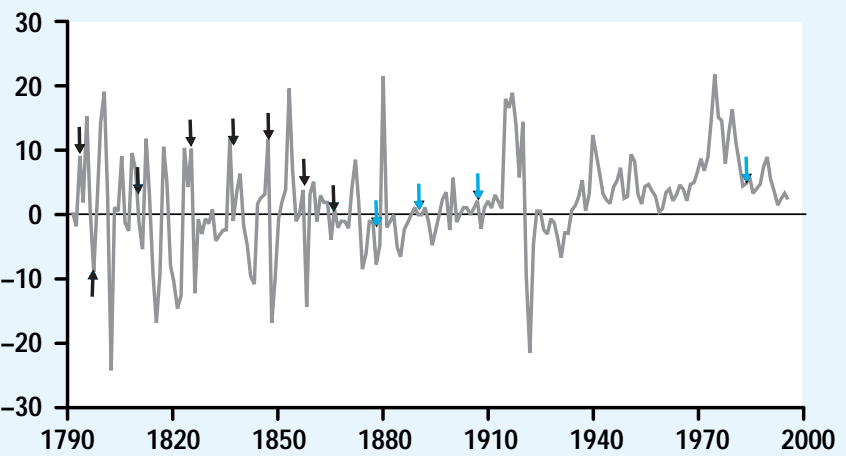

NOTE: Black arrows mark years in which banking panics occurred. Blue arrows mark years in which other severe banking instability occurred.

consistency of monetary policy between the 1920s and early 1930s, however, and, for the most part, conclude that the Fed's response to the Great Depression could have been anticipated from its past actions (see Wicker, 1966; Brunner and Meltzer, 1968; and Wheelock, 1991).

Direct evidence on price level expectations during the Depression is, unfortunately, similarly cloudy. Among recent studies, Hamilton (1992) argues that futures market trading indicates that much of the decline in commodity prices (and by extension the aggregate price level) was not expected. But based on analysis of univariate time-series models of inflation and estimates of the real interest rate, Cecchetti (1992) concludes that deflation, at least at short (three- to six-month) horizons, was substantially expected. Evans and Wachtel (1993), however, contend that such models are biased. Their own analysis suggests that the deflation of the Great Depression was largely unexpected.

In sum, the evidence for whether either monetary policy actions or movements in the price level during the Depression could have been anticipated is mixed. It seems unlikely, however, that either the timing of the initial downturn and subsequent shocks or the length and severity of the deflation could have been fully expected. We conclude therefore that unanticipated deflation probably played an important exacerbating role in the financial distress of 1930-33.

\section{The United Kingdom and Canada}

We now turn to the historical experiences of the United Kingdom and Canada.

The British historical experience with price and financial instability before World War I can be viewed as a useful comparison to that of the United States. The experience can be divided into two parts: 1) 1790-1866 - a period of both price level (inflation) and financial instability quite similar to that of the United States; 2) 1866-1914-when price behavior was again like that of the United States, but no banking panics occurred. There were, however, other nonpanic episodes of banking distress in this period.

\section{The United Kingdom}

1790-1866. In the period 1790-1866, financial instability occurred under two circumstances: wartime shocks, and following or coincident with cyclical and inflation peaks as suggested by the Schwartz Hypothesis. Many factors at work over the business and inflation cycle help explain the pattern observed in Figure 6 where, alongside the U.K. inflation rate we have marked with black arrows years in which banking panics occurred and with blue arrows years in which other serious banking instability occurred. Shocks precipitating banking instability in the United Kingdom included real shocks, such as domestic harvest failures and wars; stock market and commodity price speculation; the operation of the classical gold standard price-specie-flow mechanism and the Bank of England's pursuit of the rules of the game; and the Bank of England's failure to act as an effective lender of last resort. We emphasize these factors in our brief narrative of the banking distress of the period, which is based on Thorp (1926), Gayer, Rostow and Schwartz (1953), and Clapham (1945). 


\section{REVIEW}

SEPTEMBER/ OCTOBER 1998

The price levels of the United Kingdom and the United States moved in concert during the period as the countries were linked by the international gold standard and trade flows. Episodes of financial and economic distress tended to coincide across countries.

1793. The first financial crisis that was characterized by widespread bank runs and failures occurred at the outbreak of war with France in 1793. Consistent with the Schwartz Hypothesis, the crisis followed several years of rising prices and an economic boom. The price level peaked at the time of the crisis. According to Gayer, Rostow and Schwartz (1953, p. 7), "There would probably have been a 'crisis of 1793' even if war had not broken out."

1797. In February 1797, the Bank of England suspended gold convertibility under government authorization. France's return to gold convertibility and fears of invasion had triggered both an external drain on the gold reserves of the Bank of England and a conversion of bank notes and deposits into specie within the United Kingdom. A more fundamental cause of the suspension was the Bank's large issuance of notes to aid the government in war finance, which the Bank could no longer freely convert into specie at the existing parity (see Bordo and Schwartz, 1996). As in the United States, however, the crisis was preceded by declining prices and recession and hence was probably exacerbated by the mechanism described by the Schwartz Hypothesis.

1810. A mild banking panic occurred following a collapse of speculation in South American stocks and the subsequent loosening and tightening of Napoleon's Continental blockade in 1810. It was preceded by an inflation fueled by fiat money (Bank of England and country bank notes), but the panic occurred after the price peak, thus again suggesting that unanticipated disinflation contributed to the financial distress.

1825. The United Kingdom suffered a severe financial crisis in 1825, unlike the United States where the crisis was fairly minor. A major banking panic followed an episode of booming real activity, rising commodity prices and speculation in Latin American stocks. The boom was fueled by country bank credit and a highly accommodative policy of the Bank of England following the resumption of specie payments in 1821 ( Neal, 1998; Bordo, 1998). The Bank reacted to declining gold prices, (a result of a rising trade deficit) in late 1824 by selling exchequer bills. This triggered a stock market crash in April 1825, a downturn in commodity prices, bank failures, and a banking panic in December. The Bank acted too late in providing liquidity to the market to prevent widespread bank failures and bankruptcies.

As with several subsequent crises in the United Kingdom and the United States, it is difficult to disentangle the causal direction between financial distress and disinflation in 1825. Though banking panics may be triggered by disinflation, they tend also to precipitate falling prices by causing monetary contraction. Causality is especially difficult to identify for the United Kingdom, where early nineteenth century crises often originated from changes in Bank of England policy. For the United States, where foreign shocks reverberated through gold and trade flows, changes in the price level were more obviously exogenous. Nevertheless, as in later episodes, the extant evidence for 1825 indicates that business failures, personal bankruptcies, and other forms of financial distress arose in the disinflation that followed the initial panic (see Neal, 1998).

1837-39. Like the 1825 crisis, the 1837 crisis was preceded by a run up in commodity prices and a stock market boom (Temin, 1969; Lévy-Leboyer, 1978). The Bank of England, in the face of an external drain, raised its discount rate, which quickly ended the boom, turned prices around, and led to panic and recession. The following year, both output and prices recovered and a similar pattern, characterized by an internal drain, a rise in Bank Rates, a decline in prices, and a mild panic, ensued. Bank of England policy and subsequent declines in commodity prices, as discussed previously, appear to have been the cause of financial distress in 
the U nited States, where the crises were especially severe.

1847. The early 1840s in the United Kingdom, as in the United States, was a period of recession and deflation, followed by recovery, rising prices, and a boom in British railroad stocks. As in earlier episodes, the balance of trade turned negative. The Bank of England reacted to declining gold reserves by raising its discount rate. This ended the boom, caused prices to fall, and triggered a major banking panic, which ended only with an announcement that the chancellor of the exchequer had signed a letter temporarily suspending the Bank Charter Act, thereby allowing the Bank to issue more notes than would be covered by its gold reserves. Once again, financial distress was associated with falling prices, consistent with the Schwartz Hypothesis, though, like the crises of 1825 and 1837-39, the direction of causality between prices and financial distress is difficult to disentangle.

1857. The U.K. financial crisis of 1857 was similar. The late 1840 s into the 1850 s was a boom period, with rising prices around the world caused by gold discoveries in Australia and California (Bordo, 1975). The 1857 crisis started in the United States. The suspension of convertibility then spread to England through correspondent banks in Liverpool. At the same time the Bank of England raised Bank Rate to stem a gold drain. Commodity prices peaked just before the panic.

1866. The last panic in Britain followed the pattern of the preceding ones. The late 1850 s into the 1860 s was also a period of prosperity, rising prices, and stock market speculation. The panic of 1866 was triggered by a rise in Bank Rate in May and the collapse of Overend Gurney and Company, a major discount house that had financial difficulties for many years (Batchelor, 1986). The Bank of England's refusal to provide assistance to Overend Gurney led to a banking panic, which was ended (as were the two previous episodes) by temporary suspension of the Bank Charter Act.

In summary, as in the United States, episodes of severe financial distress in the United Kingdom from the 1790 s to 1866 were associated with sharp movements in the rate of inflation. Stock market crashes and banking panics often occurred soon after price level peaks that followed sustained inflations. Bankruptcies and other forms of financial distress then followed in subsequent disinflationary periods. The evidence thus seems largely consistent with the Schwartz Hypothesis.

1867-1914. In the next 60 years, the pattern of repeated cycles in output and prices, stock market booms and busts, and gold flows (with a Bank of England rules of the game reaction) in response to price level movements continued, but there were no banking panics. In this period the Bank learned to act as a lender of last resort and followed Bagehot's rule "to lend freely but at a penalty rate" in the face of both an external and internal drain. In addition, the U.K. banking system underwent consolidation, which further contributed to its stability. Thus the various international financial crises that rocked the gold standard had only limited effects in Britain (Kindleberger, 1978; Bordo, 1986). Moreover, movements in the U.K. price level, as in the U.S. price level, were comparatively small during the period.

The crisis of 1873, which ravaged the United States and the continent, was associated with a downturn in prices and a rise in Bank Rate, but no panic. In 1878, a major bank failure in Scotland, the City of Glasgow Bank, created financial stringency there but little spillover to England. In 1890 a major banking panic was averted after the failure of Barings. Its collapse was triggered by debt default in Argentina. Panic in London was prevented by the Bank of England arranging a "lifeboat" operation whereby the government guaranteed loans by other London banks to recapital ize Barings. The Bank was also aided by short-term loans from the Banque de France and the Russian Central Bank.

The international crises of 1893 , 1900, and 1907 also had limited effect on the British financial system. In the last case, prices peaked and the stock market collapsed but, unlike New York, no banks failed. 


\section{REVIEW}

September/ O Ctober 1998

The final episode was 1914. A meltdown of the international financial system did not lead to a banking panic in the United Kingdom because of massive central bank assistance to the financial markets (Seabourne, 1986).

After World War I, Britain experienced deflation and economic weakness through much of the 1920s. The United Kingdom returned to the gold standard at pre-war parity in 1925 but had difficulty maintaining its gold reserves. The big crisis of 1931, which forced sterling off gold and was triggered by both a banking and currency crisis in Central Europe, had little effect on the British financial system (Capie and Wood, 1986). Once Britain left the gold standard, the nation's price level began to rise and its economy began to recover from the Great Depression (Eichengreen, 1992).

To summarize, the United Kingdom, unlike the United States, did not experience banking panics or their contractionary effects after 1866. This contrast was due to timely lender of last-resort intervention by the Bank of England, as well as the U.K.'s inherently more stable banking system, and not to differences in the two countries' inflation experiences. Neither country had large swings in inflation from the 1870 s to 1914 , and so their experiences shed little light on the Schwartz Hypothesis. The Great Depression, by contrast, was associated with substantial deflation and financial distress, particularly in the United States.

In the post-World War II period, both the United Kingdom and the United States experienced an increase in financial distress during the disinflationary episode of the early 1980s. The Bank of England staged bailouts of the fringe banks in 1974 and Johnson Mathey in 1982. Consistent with the Schwartz Hypothesis, these episodes of increased banking losses and failure occurred in periods of disinflation.

\section{Canada}

Over the period 1867-1914, macroeconomic fluctuations in Canada coincided closely with those of the United States and

\section{Figure 7}

Annual Inflation Rate in Canada

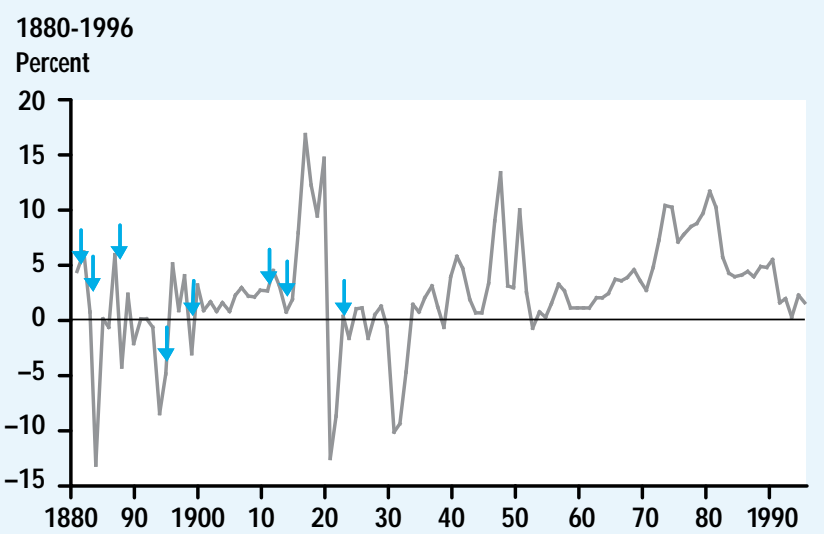

NOTE: Blue arrows mark years of high depositor losses associated with bank failures.

the United Kingdom. And, like the United Kingdom but unlike the United States, Canada had no banking panics, thanks to its highly concentrated and regionally diversified banking system. Moreover, despite the absence of a well-devel oped lender of last resort, the Department of Finance issued Dominion notes (convertible government notes) to allay financial stringency during the Panic of 1907 in N ew York. On other occasions, the Bank of M ontreal, the largest chartered bank, cooperated with the other banks to arrange mergers for banks in financial straits.

Still, Canada suffered a number of bank failures associated with loan losses. Figure 7 plots the inflation rate in Canada along with blue arrows in years of high depositor losses associated with bank failures. In the period 1867-1900, Canadian rates of losses to depositors and note holders were in some years higher than similar rates for U.S. national banks, although not for all U.S. banks (Bordo, Rockoff, and Redish, 1996). In Canada, these losses all occurred in isolated individual, but relatively large, bank failures, and most occurred during the period of secular deflation, 1873-1898, consistent with the Schwartz Hypothesis. Losses virtually disappeared after 1900 following a vigorous merger movement, 
which consolidated the regional banks and created a system of a small number of highly concentrated nationwide branch banks. The absence of prohibitions on branch banking or interprovincial banking, which prevailed in the United States, explains why Canadian banks failed occasionally because of poor judgement or fraud, but not as a consequence of regional shocks or even nationwide shocks (Bordo, Redish and Rockoff, 1995, and Bordo, Rockoff and Redish, 1996).

After 1914, Canada experienced only one major bank failure, the Home Bank in 1923, although Canadian banks were severely stressed during the Great Depression, when business failures and other types of financial distress rose while the price level fell. Similarly, in 1984, many small banks failed and were bailed out by the Bank of Canada. Thus the timing between disinflation and financial distress in Canada was similar to that of the United States and United Kingdom. Institutional differences, not inflation patterns, account for the different forms that banking distress took in the three countries.

\section{CONCLUSION}

The Schwartz Hypothesis argues that unexpected disinflation causes or worsens financial instability by lowering the nominal returns to investment below what had been anticipated as well as by raising the real burden of nominal debt above what it had been expected to be. Schwartz (1997, p. 102) argues that "Ienders and borrowers both evaluate the prospects of projects by extrapolating the prevailing price level or inflation rate. A subsequent decision by monetary authorities to pursue contractionary policies will undermine the price-level assumptions of both lenders and borrowers. That is why borrowers default and lenders become distressed."

Some researchers have concluded that substantial fluctuations in the rate of inflation have contributed to financial instability in many countries in the early 1990s. ${ }^{19}$ From our review of episodes of serious financial instability in U.S. financial history, supple- mented by the experiences of the United Kingdom and Canada, we conclude that price level instability also contributed to financial instability historically. Regardless of what triggers financial distress, be it monetary or nonmonetary forces, the most severe episodes of instability have occurred typically in disinflationary environments. This has not al ways been true, however. Severe banking panics occurred in the United States in the late nineteenth and early twentieth centuries, when the price level was comparatively stable. Still, before the Civil War, during the Great Depression, and since World War II, financial distress was typically most severe during periods of substantial disinflation. The historical record thus suggests that a monetary policy that focuses on limiting fluctuations in the price level will tend also to promote financial stability.

\section{REFERENCES}

Alston, Lee J., Wayne A. Grove, and David C. Wheelock. "Why Do Banks Fail? Evidence from the 1920s," Explorations in Economic History (October 1994), pp. 409-31.

Barsky, Robert B. "The Fisher Hypothesis and the Forecastability and Persistence of Inflation," Joumal of Monetary Economics (January 1987), pp. 3-24

Batchelor, Roy A. "The Avoidance of Catastrophe: Two NineteenthCentury Banking Crises," in Forrest Capie and Geoffrey E. Wood, eds., Financial Crises and the World Banking System, St. Martin's Press, 1986, pp. $41-73$.

Bordo, Michael D. "Comment on Larry Neal, 'The Bank of England's First Return to Gold and the Stock Market Crash of 1825,'" this Review (May/ June 1998), pp. 77-82.

"Financial Crises, Banking Crises, Stock Market Crashes and the Money Supply: Some Intermational Evidence, 1870-1933," in Forrest Capie and Geoffrey E. Wood, eds., Financial Crises and the World Banking System, St. Martin's Press, 1986, pp. 190-248.

"The Classical Gold Standard: Some Lessons for Today," this Review (May 1981), pp. 2-17.

"J ohn E. Cairnes on the Effects of the Australian Gold Discoveries 1851-73: An Early Application of the Methodology of Positive Economics," History of Political Economy (Fall 1975), pp. 337-59.

and Finn E. Kydland. "The Gold Standard as a Rule: An Essay in Exploration," Explorations in Economic History (October 1995), pp. 423-64. 


\section{REVIEW}

SEPTEMBER/ OCTOBER 1998

, Hugh Rockoff, and Angela Redish. "A Comparison of the Stability and Efficiency of the Canadian and American Banking Systems 1870-1925," Financial History Review (April 1996), pp. 49-68.

, Angela Redish, and Hugh Rockoff. "A Comparison of the United States and Canadian Banking Systems in the Twentieth Century: Stability vs. Efficiency?" in Michael D. Bordo and Richard Sylla, eds., Anglo-American Financial Systems: Institutions and Methods in the Twentieth Century, Irwin Professional Publishers, 1995, pp. 11-40.

, and Anna J. Schwartz. "Why Clashes Between Internal and External Stability Goals Result in Currency Crises, 1797-1994," Open Economies Review (Supplement 1 1996), pp. 437-68.

Brunner, Karl, and Allan H. Meltzer. "What Did We Leam from the Monetary Experience of the United States in the Great Depression?" Canadian Joumal of Economics (May 1968), pp. 334-48.

Cagan, Philip. Determinants and Effects of Changes in the Stock of Money 1875-1960, Columbia University Press, 1965.

Calomiris, Charles W. "Greenback Resumption and Silver Risk: The Economics and Politics of Monetary Regime Change in the United States, 1862-1900," in Michael D. Bordo and Forrest Capie, eds., Monetary Regimes in Transition, Cambridge University Press, 1993, pp. 86-134.

"Do 'Vulnerable' Economies Need Deposit Insurance? Lessons from the U.S. Agriculture in the 1920s," in Philip L. Brock, ed. If Texas Were Chile: A Primer on Banking Reform, Institute for Contemporany Studies, 1992, pp. 237-314.

, and Christopher Hanes. "Consistent Output Series for the Antebellum and Postbellum Periods: Issues and Preliminary Results," Journal of Economic History (June 1994), pp. 409-22.

, and Gary Gorton. "The Origins of Banking Panics:

Models, Facts, and Bank Regulation," in R. Glenn Hubbard, ed. Financial Markets and Financial Crises, University of Chicago Press, 1991, pp. 109-73.

, and Larry Schweikart. "The Panic of 1857: Origins,

Transmission and Containment," Joumal of Economic History (December 1991), pp. 807-34.

Capie, Forrest, and Geoffrey E. Wood. "Introduction," in Forrest Capie and Geoffrey E. Wood, eds., Financial Crises and the World Banking System, St. Martin's Press, 1986, pp. 1-10

Cargill, Thomas F., Michael N. Hutchinson, and Takatoshi Ito. "Preventing Future Banking Crisis in Japan," prepared for Preventing Banking Crises: Analysis and Lessons from Recent Global Bank Failures, conference sponsored by the Federal Reserve Bank of Chicago and the World Bank, June 1997.
Cecchetti, Stephen G. "Prices During the Great Depression: Was the Deflation of 1930-32 Really Unanticipated?" American Economic Review (March 1992), pp. 141-56.

Clapham, Sir John. The Bank of England, MacMillan, 1945.

David, Paul A., and Peter Solar. "A Bicentenary Contribution to the History of the Cost of Living in America," Research in Economic History (1977), pp. 1-80.

Diamond, Douglas W., and Phillip H. Dybvig. "Bank Runs, Deposit Insurance, and Liquidity," Journal of Political Economy (J une 1983), pp. 401-19.

Eichengreen, Barry. Golden Fetters: The Gold Standard and the Great Depression, 1919-1939, Oxford University Press, 1992.

Evans, Martin, and Paul Wachtel. "Were Price Changes During the Great Depression Anticipated? Evidence from Nominal Interest Rates," Journal of Monetary Economics (August 1993), pp. 3-34.

Fisher, Irving. "The Debt Deflation Theory of Great Depressions," Econometrica (1933), pp. 337-57. Booms and Depressions, Adelphi, 1932.

Friedman, Benjamin. "Increasing Indebtedness and Financial Stability in the United States," in Debt, Financial Stability and Public Policy, Federal Reserve Bank of Kansas City, 1986, pp. 27-53.

Friedman, Milton. "The Crime of 1873," Journal of Political Economy (December 1990), pp. 1159-94.

Friedman, Milton, and Anna J. Schwartz. A Monetary History of the United States, 1867-1960. Princeton University Press, 1963.

Gavin, Michael and Ricardo Hausmann. "The Roots of Banking Crises: The Macroeconomic Context," in Ricardo Hausmann and Liliana RojasSuárez, eds., Banking Crises in Latin America, Inter-American Development Bank, 1996, pp. 27-63.

Gayer, Arthur D., W. W. Rostow, and Anna J. Schwartz. The Growth and Fluctuation of the British Economy, 1790-1850. Clarendon Press, 1953.

Gorton, Gary. "Clearinghouses and the Origin of Central Banking in the U.S.," Journal of Economic History (June 1985), pp. 277-83.

Hamilton, James D. "Was the Deflation During the Great Depression Anticipated? Evidence from the Commodity Futures Market," American Economic Review (March 1992), pp. 157-78. . "Monetary Factors in the Great Depression," Journal of Monetary Economics (March 1987), pp. 145-69.

Intemational Monetary Fund. World Economic Outlook, Interim Assessment, December 1997.

Jacklin, Charles |., and Sudipto Bhattacharya. "Distinguishing Panics and Information-Based Bank Runs: Welfare and Policy Implications," Journal of Political Economy (June 1988), pp. 568-92. 
Jonung, Lars. "Depression in the North: Boom and Bust in Sweden and Finland, 1985-1993," International Monetary Fund seminar paper, 1994.

Kaufman, Henry. "Debt: The Threat to Economic and Financial Stability," in Debt, Financial Stability and Public Policy, Federal Reserve Bank of Kansas City, 1986, pp. 15-26.

Kindleberger, Charles P. Manias, Panics and Crashes: A History of Financial Crises, Basic Books, 1978.

King, Mervyn. "Debt Deflation: Theory and Evidence," European Economic Review (April 1994), pp. 419.45.

Lévy-Leboyer, Maurice. "Central Banking and Foreign Trade: The AngloAmerican Cycle in the 1830s," in Charles P. Kindleberger and JeanPierre Laffargue, eds., Financial Crises: Theory, History and Policy, Cambridge University Press, 1978, pp. 66-110.

Lucas Jr, Robert E. "Some Intermational Evidence on Output-Inflation Tradeoffs," American Economic Review (June 1973), pp. 326-34.

_..... . "Expectations and the Neutrality of Money," Journal of Economic Theory (April 1972), pp. 103-24.

Minsky, Hyman. "A Theory of Systemic Fragility," in Edward I. Altman and Arthur W. Samezz, eds., Financial Crises. Institutions and Markets in a Fragile Environment, Wiley, 1977, pp. 138-52.

Mitchell, Brian R. Abstract of British Historical Statistics, Cambridge University Press, 1962.

Neal, Larry. "The Bank of England's First Return to Gold and the Stock Market Crash of 1825," this Review (Mayl June 1998), pp. 53-76.

Romer, Christina. "World War I and the Postwar Depression: A Reinterpretation Based on Alternative Estimates of GNP," Joumal of Monetary Economics (July 1988), pp. 91-115.

Schwartz, Anna J. "Comment on 'Debt-Deflation and Financial Instability: Two Historical Explorations' by Barry Eichengreen and Richard S. Grossman," in Forrest Capie and Geoffrey E. Wood, eds., Asset Prices and the Real Economy, St. Martin's Press, 1997, pp. 100-105. . "Why Financial Stability Depends on Price Stability," Economic Affairs (Autumn 1995), pp. 21-25.

_. . _. "Real and Pseudo-financial Crises," in Forrest Capie and Geoffrey E. Wood, eds., Financial Crises and the World Banking System, St. Martin's Press, 1986, pp. 11-31.

"Financial Stability and the Federal Safety Net," in William S. Haraf and Rose Marie Kushneider, eds., Restructuring Banking and Financial Services in America, American Enterprise Institute, 1988, pp. 34-62.

"Understanding 1929-1933," in Karl Brunner, ed., The Great Depression Revisited, Martinus Nijhoff, 1981, pp. 5-48.

Seaboume, Teresa. "The Summer of 1914," in Forest Capie and Geoffrey E. Wood, eds., Financial Crises and the World Banking System, St. Martin's Press, 1986, pp. 77-116.
Smith, Walter B., and Arthur Harrison Cole. Fluctuations in American Business, 1790-1860, Harvard University Press, 1935.

Sprague, O. M. W. History of Crises Under the National Banking System, Government Printing Office, 1910.

Sylla, Richard. "U.S. Capital Markets and the Banking System, 1790 1840," this Review (May/ June 1998), pp. 83-98.

Temin, Peter. The Jacksonian Economy, W. W. Norton, 1969.

Thorp, Willard Long. Business Annals, National Bureau of Economic Research, 1926.

Wheelock, David C. "Government Policy and Banking Market Structure in the 1920s," Journal of Economic History (December 1993), pp. 857-79.

The Strategy and Consistency of Federal Reserve
Monetary Policy, 1924-1933, Cambridge University Press, 1991.

Wicker, Elmus. The Banking Panics of the Great Depression, Cambridge University Press, 1996.

. Federal Reserve Monetary Policy 1917-1933,

Random House, 1966. 